УДК [94 + 327(091)](470+571 + 474-89)“13/15“; ББК 63.3(2)43+63.3(0)4-6;

DOI https://doi.org/10.21638/11701/spbu19.2019.211

Ф. Д. Подберёзкин

КОГДА ПОЯВИЛАСЬ ЮРЬЕВСКАЯ ДАНЬ?

ВОПРОС О «ЮРЬЕВСКОЙ ДАНИ» НА РУССКО-ЛИВОНСКИХ ПЕРЕГОВОРАХ 1554 ГОДА

С 28 апреля по 1 июня 1554 г. в Москве между послами ливонской конфедерации и представителями русского царя Ивана IV окольничим Алексеем Федоровичем Адашевым и дьяком Иваном Михайловичем Висковатым проходили напряженные переговоры о заключении мирного договора ${ }^{1}$. Переговоры начались с предъявления русской стороной письменных претензий ливонцам. Среди прочего указывалось, что епископ Дерпта (рус. - Юрьева) должен заплатить «дань по старине со всеми старыми задолженностями, согласно крестному изелованию и праву» ${ }^{2}$.

Немецкие послы отвечали, что «ни один человек в Ливонии, хотя бы ему было и 200 лет от роду, не знает, что это за дань», сам пункт о дани в предыдущих руссколивонских договорах является ничем иным, как выражением «величия, почести изарю и государю всея Руси», а «по-другому дань в епископстве никто не понимает, не воспринимает и не толкует» ${ }^{3}$.

Дальнейшие действия русских представителей свидетельствовали о заранее подготовленной реакции на «неведение» ливонцев. Дьяк Висковатый сказал, что дань,

${ }^{1}$ Отчет о переговорах ливонских посланников с «князем» Алексеем Федоровичем Адашевым и с дьяком Иваном Михайловичем Висковатым. 28 апреля - 1 июня 1554 г. // Щербачев Ю. Н. Копенгагенские акты, относящиеся к русской истории. М., 1915. Вып. 1. С. 23-38. № 20. Специальное исследование вопроса о «юрьевской дани» во время переговоров 1554 г. см.: Шаскольский И. П. Русско-ливонские переговоры 1554 года и вопрос о ливонской дани // Международные связи России до XVII в. М., 1961. С. 376-399. - См. также: Филюшкин А. И., Попов В. Е. Русско-ливонские договоры 1554 г. // Studia Slavica et Balcanica Petropolitana. 2010. № 1 (7). С. 109-130 (публикация русских вариантов новгородско-ливонского и псковско-дерптского договоров). - Обобщающее исследование дискурсивных практик Ливонской войны см.: Филюшкин А. И. Изобретая первую войну России и Европы. Балтийские войны второй половины XVI в. глазами современников и потомков. СПб., 2013.

${ }^{2}$ Отчет о переговорах... С. 25. - Здесь и далее перевод выполнен автором статьи.

${ }^{3}$ Там же. C. 26, 31.

(С) Ф. Д. Подберёзкин, 2019 
которую не платили «в течение 210 лет», положено давать «с каждой головы» жителей Дерптского епископства; под пунктом о дани в тексте договора «982 года» «подписались и иуеловали крест» сами дерптцы, «а то, чего не хотят исполнить, не удостоверяют u не подписывают» (имелся в виду договор 6982, то есть 1474 г.)4. Специально подобранные исторические и правовые аргументы в конце концов вынудили послов подписать изначально одобренный царем текст докончальной грамоты, где епископ Дерпта обязывался платить дань «по старине» ${ }^{5}$.

\section{ИСТОРИЧЕСКИЙ КАЗУС}

Наличие правовых оснований для «юрьевской дани» несомненно - после упомянутого Иваном Висковатым русско-ливонского договора 1474 г. пункт о дани действительно повторяется в последующих договорах Пскова и Дерпта 1509, 1550, 1554 гг. Вопросы вызывает казус исторический. Как более ста лет назад справедливо отмечал историк Иван Юрьенс ${ }^{7}$, важны не размер и доходность дани, а ее «принципиально историческое значение» ${ }^{8}$ в качестве обоснования претензий русских государей на Ливонию.

Неясность обусловлена состоянием источников. Во второй половине 50-х гг. XVI в. история происхождения «юрьевской дани» адресовалась как иностранным послам 9 ,

\footnotetext{
${ }^{4}$ Висковатый ссылается на русско-ливонский договор 1474 г., где присутствует пункт о «юрьевской дани» (Договорная грамота Великого Новгорода и Пскова с епископом юрьевским о перемирии на 30 лет, 13 января 1474 г. // Грамоты Великого Новгорода и Пскова / Под ред. С. Н. Валка. М., Л., 1949. С. 133. № 78; см. также: Баранов А. В. Русско-ливонские договоры 1474 года: предпосылки, переговоры, последствия // Средневековая Русь. 2016. Вып. 12. С. 201-282). В тексте Псковской Третьей летописи упоминается более ранний договор 1463 г., где говорится о «послине великих князей», взимаемой с дерптского епископа в пользу великого князя московского (Псковские летописи. Вып. 2 / Изд. подгот. А. Н. Насонов. М., 1955. С. 155-156). Реальность этого договора сомнительна (см.: Казакова Н. А. Русь и Ливония 60-x - начала 90-х годов XV века // Международные связи России до XVII в. M., 1961. С. 323). Однако не подлежит сомнению, что дьяк Висковатый и окольничий Адашев предъявили ливонской стороне оригинальный текст русско-ливонского соглашения с печатями и подписями.

${ }^{5}$ Отчет о переговорах... С. 37-38.

${ }^{6}$ Шаскольский И. П. Русско-ливонские переговоры 1554 г. ... С. 381; Филюшкин А. И., Попов B. E. Русско-ливонские договоры 1554 г. ... С. 112, 125.

${ }^{7}$ Jaan Jürjens (эстонский вариант), Ivan Jürgens (немецкий вариант).

${ }^{8}$ Юрьенс И. А. Вопрос о ливонской дани // Варшавские университетские известия. 1913. Вып. VI. C. 1.

${ }^{9}$ Например: Franz Nyenstaedt's Livländische Chronik nebst dessen Handbuch // Monumenta Livoniae antiquae. Bd 2 / Hrsg. von G. Tielemann. Riga; Leipzig, 1839. S. 44-45; Ответ датским послам на ходатайство датского короля Фредерика о прекращении военных действий, предпринятых против магистра Ливонскаго за его «неисправления», 5 апреля 1559 г. // Русские акты Копенгагенского государственного архива, извлеченные Ю. Н. Щербачевым / Под ред. И. А. Бычкова. СПб., 1897. С. 45-46. № 16; Отчет о переговорах... С. 119-120, 147; Курбский А. М. История о делах великого князя Московского / Изд. подг. К. Ю. Ерусалимский. М., 2015. С. 84-86; Посольство от короля Сигизмунда Августа к царю Ивану Васильевичу с панами Юрием Александровичем Хоткевичем, Григорием Воловичем и писарем Михаилом Халабурдой для переговоров о мире, 18 ноября 1563 - 9 января 1564 // Сборник Императорского Русского исторического общества. Т. 71. СПб., 1892. С. 216 . № 12.
} 
так и подданным русского царя Ивана Васильевича ${ }^{10}$. На наш взгляд, в окончательном виде эта история присутствует в «Степенной книге царского родословия» ${ }^{11}$. Согласно ей, русские государи издревле владели Ливонией (ранее называемой «Чюдь»). Великий князь Ярослав Владимирович в 1030 г. основал в этих землях город Юрьев «в свое имя». Тамошние епископы, «пришедиие из-за моря» ${ }^{12}$, регулярно платили дань Новгороду и Пскову. Затем, «претворив Юрьевскую епископию в латыньское бископство», ливонцы перестали платить дань ${ }^{13}$.

Однако в летописных сообщениях об основании Юрьева в 1030 г., о последующих походах русских князей на этот город, часто почти буквально цитируемых составителями «Степенной книги», собственно о «юрьевской дани» ничего не сказано ${ }^{14}$. Данное обстоятельство объясняет существование в исторической литературе трех основных версий происхождения «юрьевской дани»: так называемой «медовой дани» ${ }^{15}$, дани «правой веры» ${ }^{16}$, дани Толовы ${ }^{17}$. В виду «молчания» источников все версии базируются на поиске исторического прецедента, который мог послужить «стариной» пункта о дани в русско-ливонских договорах 1463 и 1474 гг. (первые дошедшие до нас письменные упоминания). На наш взгляд, эти версии обладают приблизительно равной степенью достоверности. Как заключил эстонский историк Анти Селарт, «отношения Пскова и Дерпта в Средние века были настолько сложными, что существовало множество возможностей для возникновения дани» ${ }^{18}$.

${ }^{10}$ Полное собрание русских летописей. Т. 13. Летописный сборник, именуемый Патриаршею или Никоновскою летописью. М., 2000. С. 240; Степенная книга царского родословия: тексты и комментарий / Отв. ред. Н. Н. Покровский, Г. Д. Ленхофф. Т. 1. Житие св. княгини Ольги: степени I-X. М., 2007. С. 380-382.

${ }^{11}$ Подробнее см.: Selart A. Livland - ein russisches Erbland? // Russland an der Ostsee. Imperiale Strategien der Macht und kulturelle Wahrnehmungsmuster / Hrsg. von K. Brüggemann und B. D. Woodworth. Wien; Köln; Weimar, 2012. S. 61-62.

${ }^{12}$ Вероятнее всего, здесь имеются в виду первые немецкие епископы Ливонии (Мейнард, Бертольд, Альберт). На изначальное «православие» ливонских епископов указывает дальнейший пассаж «претворения в латыньское бископство».

${ }^{13}$ Степенная книга... С. 380-382.

${ }^{14}$ Повесть временных лет / Под ред. В. И. Адриановой-Перетц. СПб., 1996. С. 65; Новгородская Первая летопись Старшего и Младшего изводов / Под ред. А. Н. Насонова. М., 1950. C. $23,40,73,83,183$.

${ }^{15}$ Согласно версии «медовой дани», псковичи брали деньги с жителей округи Нейгаузена за пользование медовыми деревьями, находившимися во владениях Пскова, см.: Schiemann T. Rußland, Polen und Livland bis ins 17. Jahrhundert. Bd 2. Berlin, 1887. S. 143-144; Форстен Г. В. Балтийский вопрос в XVI и XVII столетиях (1544-1648). Т. 1. СПб., 1893. С. 86; Arbusow L. Grundriß der Geschichte Liv-, Est- und Kurlands. Riga, 1918. S. 173-174.

${ }^{16}$ Немецко-балтийский историк Карл фон Штерн считал, что истоки «юрьевской дани» в обязательстве властей Дерпта платить на содержание тамошних православных церквей (Stern C. Der Vorwand zum grossen Russenkriege 1558. Riga, 1936).

${ }^{17}$ По мнению Ивана Юрьенса, требования «ливонской дани» Иваном IV имеют прецедент в дани Толовы - латгальской области, где псковичи собирали дань еще в XIII в., см.: Юрьенс И. А. Вопрос о ливонской дани // Варшавские университетские известия. 1913. Вып. VI. C. 1-8; Вып. VII. C. 9-16; Вып. VIII. С. 17-32; Вып. IX. С. 33-57.

${ }^{18}$ Selart A. Der «Dorpater Zins» und die Dorpat-Pleskauer Beziehungen im Mittelalter // Aus der Geschichte Altlivlands: Festschrift für Heinz von zur Mühlen zum 90. Geburtstag / Hrsg. von B. Jähnig und K. Militzer. Münster, 2004. S. 36. 


\section{0 ЛЕТ: ОТКУДА ОТСЧИТЫВАТЬ ХРОНОЛОГИЮ ДАНИ}

В исторической литературе недостаточно внимания уделялось датировкам «200 лет» ${ }^{19}$ и «210 лет» $»^{20}$, которые приводились самими послами и дьяком Иваном Висковатым ${ }^{21}$. Если цифра «200» была высказана послами скорее в метафорическом духе претензии на communis opinio ${ }^{22}$, то ответ в «210 лет» неуплаченной дани в устах дьяка прозвучал и риторично («210» вместо «200»), и исторично ${ }^{23}$. Кроме самой констатации, в тексте отчета о переговорах ливонских послов с Алексеем Адашевым и Иваном Висковатым нет упоминаний о каком-либо происшествии, которое можно было бы «привязать» к конкретной цифре «210» ${ }^{24}$. В данном исследовании мы будем позитивно исходить из данных русской стороны и попытаемся найти событие, с которого начался отсчет хронологии «юрьевской дани».

Предварительно следует выяснить, с какого времени, по мнению русских дипломатов, ливонцы могли перестать платить дань. Приведем здесь слова дьяка Ивана Висковатого в пересказе ливонских послов:

«канцлер... объявил, что дань не платилась от государя к государю в течение 210 лет, и что

81 год назад она снова была включена в мирный договор, после этого из года в год ее подтверждали, обещали и целовали крест, однако она так никогда и не была уплачена» ${ }^{25}$.

Фраза «81 год назад» указывает на русско-ливонский договор 1474 г., как впоследствии дьяк уточняет ${ }^{26}$. Из того, что выражение «в течение 210 лет» стоит перед указанием на договор, можно понимать фразу так: «в течение 210 лет юрьевскую дань не платили, а после этого в 1474 г. ее вновь внесли в текст мирного договора». Таким

${ }^{19}$ Отчет о переговорах... С. 26.

${ }^{20}$ Там же. С. 31.

${ }^{21}$ Например, Игорь Павлович Шаскольский ограничивается в этом вопросе пересказом текста отчета о цифре «210» лет, приведенной Висковатым (Шаскольский И. П. Руссколивонские переговоры 1554 г. ... С. 386). Анти Селарт не идет дальше предположений о гипотетической возможности отсчитывать дань как от 1264, так и 1344 гг. (1264 г. - если отсчитывать от договора 1474 г., и 1344 г. - если считать от года переговоров 1554 г.). В 1262 г. произошла осада Дерпта русскими князьями, а в начале 40-х гг. XIV в. - пограничная война с немцами на западной границе Псковской земли от Нарвы до Адзеле (Selart A. Der «Dorpater Zins»... S. 36).

${ }_{22}$ «Hirauff gaben die gesanten diesen bericht, unss, nach keinem menschen jn Lifflant was der zinss sein sollte, wan es auch muglich, das einer ij C: jar alt were aussgenomen Rö: Kai: Mait: was zugeben pflege» (Отчет о переговорах... C. 26).

${ }^{23}$ «man solte jerlichs von jderm heubte J. m. geben, und den zinss dermaten verklaret, das er von hern zu hern, jnnerhalb ij c und x jaren nit ausgekomen» (Там же. С. 31).

${ }_{24}$ Число «210» не является сакральным и не представляет каких-либо значений, которые можно было бы понимать иначе, чем хронологически. В связи с этим представляется возможным рассматривать указание «210 лет назад» как историческое.

${ }_{25}$ «Hirentiegen cantzler herausser gefaren, man sollte jerlichs von jderm heubte J. m. geben, und den zinss dermaten verklaret, das er von hern zu hern, jnnerhalb ij und $\mathrm{x}$ jaren, nit usgekomen, und vor lxxxj widerumb ufs new jn den fried brieff gesetzet sei, were darna also von jaren zugeben belobet, beschworn und bejreutzkusset worden, aber noch niewerle entrichtet» (Отчет о переговорах... С. 31).

${ }_{26}^{26}$ Там же. С. 36. 
образом, «210 лет» следовало бы отсчитывать от 1474 г., в итоге мы бы «искали» первоначальную дань в событиях 60-х гг. XIII в.

Однако такое суждение делало бы речь Висковатого непоследовательной. Во-первых, слово о задолженности в 210 лет было конкретным ответом на фразу послов о том, что нет ни одного ливонца даже в возрасте 200 лет, который помнил бы суть этой дани (то есть 200 лет к моменту переговоров 1554 г.) $)^{27}$. Во-вторых, сам дьяк говорит, что дань никогда не платилась («noch niewerle entrichtet»), что следует понимать как «никогда не платилась в течение последних 210 лет». Таким образом, историю «неуплаты» предпочтительнее отсчитывать от 1554 г. В противном случае следовало бы прибавить к 210 годам еще 80 лет (1474-1554), что противоречит тексту источника. Значит, далее в поиске «прецедента Висковатого» мы будем исходить из событий 40-х гг. XIV в., отраженных в русских и немецких источниках.

\section{СОБЫТИЯ НА РУССКО-ЛИВОНСКОМ ПОГРАНИЧЬЕ 40-Х ГГ. XIV в.}

40-е гг. XIV в. на ливонском пограничье были отмечены серией локальных конфликтов и «больших войн» между Псковом, Новгородом, Дерптом, Витебском, Немецким орденом и Великим княжеством Литовским ${ }^{28}$. События этого времени синхронно освещаются в псковском и новгородском летописании, орденских хрониках: Виганда из Марбурга, Германа из Вартберга ${ }^{29}$. Однако наиболее подробным источником для 40-х гг. XIV в. является «Младшая ливонская рифмованная хроника» современника и очевидца событий, священника Немецкого ордена ${ }^{30}$ в Ливонии Бартоломея Хёнеке, к которой восходят данные вышеназванных хронистов. В хронике содержатся уникальные сюжеты, неучтенные ранее в историографии «юрьевской дани». Ниже будет дана общая характеристика источника, затем проанализированы интересующие нас свидетельства.

Оригинальный текст «Младшей ливонской рифмованной хроники» неизвестен. Бременский хронист XVI в., автор «Ливонской истории» («Livländische Historien») Иоганн Реннер называет рифмованное произведение Хёнеке в числе своих основных источников для периода до времен магистра Госвина фон Херике ${ }^{31}$ (избран в 1345 г.). Попытку

${ }^{27}$ Там же. С. 26, 31.

${ }_{28}^{28}$ Общая оценка этих конфликтов дана в двух статьях А. В. Мартынюка, см.: Мартынюк A. B. 1) Между Псковом, Витебском и Нейгаузеном: забытая война на ливонском пограничье в середине XIV века. Часть 1 // Ученые записки УО «Витебский государственный университет им. П. М. Машерова». Витебск, 2016. Т. 21. С. 30-36; 2) Между Псковом, Витебском и Нейгаузеном: забытая война на ливонском пограничье в середине XIV века. Часть 2 // Ученые записки УО «Витебский государственный университет им. П. М. Машерова». Витебск, 2016. T. 22. С. 33-38).

${ }^{29}$ Мартынюк А. В. Между Псковом, Витебском и Нейгаузеном... Т. 21. С. 31.

${ }^{30}$ Издатель хроники Константин Хёльбаум полагает, что Хёнеке был священником орденского замка Вейсенштейн (Die Jüngere Livländische Reimchronik des Bartholomaus Hoeneke 1315-1348 / Hrsg. von K. Höhlbaum. Leipzig, 1872. Einleitung. S. XVII). Однако, по мнению исследователя Арно Ментцель-Ройтерса, об авторе хроники можно говорить только как о священнике Немецкого ордена (Mentzel-Reuters A. Bartholomaeus Hoeneke. Ein Historiograph zwischen Überlieferung und Fiktion // Geschichtsschreibung im mittelalterlichen Livland / Hrsg. von M. Thumser. Berlin, 2011. S. 26, 30).

${ }^{31}$ «nichts anders up spoeren noch erlangen konnen dann alleine eine chronicken, so dorch einen prester Bartholomeus Hoeneken genannt vor langen jaren beth up den Meister Goswin van Hericke 
реконструкции текста хроники на основании пересказа Реннера предпринял в 1872 г. ученик Георга Вайца ${ }^{32}$, историк Константин Хёльбаум. В 2011 г. немецкий исследователь Арно Ментцель-Ройтерс признал реконструкцию Хёльбаума неудовлетворительной ${ }^{33}$. В числе прочего историк подчеркнул, что «Реннер передает нам только пустую событийную канву, из которой было удалено все, что не отвечало локально-историческому, лютеранскому интересу из XVI века» ${ }^{34}$. При этом исследователь не отрицает ни факта существования этой хроники как основного источника Реннера, ни событий, в ней описанных. Однако, в связи с изложенным, использование творения Хёнеке в качестве самостоятельного источника в дальнейшем представлялось бы невозможным. Признавая вывод Арно Ментцель-Ройтерса о проблематичности реконструкции Константина Хёльбаума, мы все же не вполне разделяем пессимизм немецкого историка.

На наш взгляд, в тексте «Ливонской истории» Иоганна Реннера можно выделить корпус оригинальных исторических сведений 40-х гг. XIV в., подчерпнутых из сообщений современника, то есть Бартоломея Хёнеке. Это касается событий русско-ливонских пограничных конфликтов, которые подробно освещаются в русском летописании. Можно отметить поразительное хронологическое, географическое и сюжетное сходство сведений, описываемых в «Младшей Рифмованной хронике» и псковских летописях ${ }^{35}$. Невозможно допустить, что Иоганн Реннер и тем более его источник из XIV в. пользовались русскими летописями. Отсюда заключаем, что события 40-х гг. XIV в., известные нам в пересказе Реннера, следует отнести на счет хроники Бартоломея Хёнеке - признавая возможность их позднейшей стилистической правки бременским историографом ${ }^{36}$.

inclusive rimeswise beschreven, welche ick under handen genamen, de rime bliven laten und historischer wise aver gesettet» (Johann Renner's Livländische Historien / Hrsg. von R. Hausmann und K. Höhlbaum. Göttingen, 1876. S. 3).

${ }_{32}$ Представители школы Георга Вайца в числе прочего специализировались на реконструкции исторических источников из позднейших компиляций.

${ }_{33}$ По мнению А. Ментцель-Ройтерса, Хёнеке писал свою хронику на восточносредненемецком диалекте, а не на нижненемецком, как утверждал К. Хёльбаум. Реннер не просто творчески перевел хронику на нижненемецкий, но и существенно изменил литературный образ хроники.

${ }^{34}$ «Renner überliefert uns nur ein geleertes Handlungsgerüst, aus dem alles entfernt wurde, was einem landesgeschichtlichen, luterisch geprägten Interesse des 16. Jahrhunderts nicht entsprach» (Mentzel-Reuters A. Bartholomaeus Hoeneke... S. 53).

${ }_{35}$ Например, история об убийстве псковских послов в 1340 г. (Die Jüngere Livländische Reimchronik... S. 10; Псковские летописи. Вып. 1 / Изд. подг. А. Н. Насонов. М., Л., 1941. С. 18), нападение русских на Латгалию зимой 1341 г. (Die Jüngere Livländische Reimchronik... S. 11; Псковские летописи. Вып. 1. С. 18), постройка немцами Нового Городка зимой 1341/1342 гг. (Die Jüngere Livländische Reimchronik... S. 13; Псковские летописи. Вып. 1. С. 18), приход литовской дружины на помощь псковичам летом 1342 г. (Die Jüngere Livländische Reimchronik... S. 18; Псковские летописи. Вып. 1. С. 18), поход 5000 русских к Одемпе весной-летом 1343 г. (Die Jüngere Livländische Reimchronik... S. 27-28; Псковские летописи. Вып. 1. С. 20) и др. Данному вопросу автор планирует посвятить отдельную статью.

${ }_{36}$ Арно Ментцель-Ройтерс публикует в своей статье «Берлинский фрагмент» из собраний Тайного государственного архива прусского культурного наследия (Mentzel-Reuters A. Bartholomaeus Hoeneke... S. 54-58). Историк полагает, что данный фрагмент может являться отрывком из хроники Хёнеке, написанной, по его мнению, на восточносредненемецком 
В хронике описываются события 1315-1348 гг. Наиболее детально представлены сведения о событиях 40-х гг. XIV в., происходивших в эстонских землях и в Дерптском епископстве со времени избрания магистра Бурхарда фон Драйлебена 24 июня 1340 г. до разгрома литовцев в битве на реке Стреве 2 февраля 1348 г. (окончание хроники). В числе прочих это обстоятельство позволило издателю источника Константину Хёльбауму полагать, что Бартоломей Хёнеке являлся очевидцем изложенных событий и жил в непосредственной близости к владениям Дерптского епископа ${ }^{37}$. Хроника доведена до 1348 г.; вероятнее всего, автор стремился продолжить труд ${ }^{38}$, однако не смог этого сделать по неизвестной нам причине. Историческое сочинение Хёнеке является основным источником по изучению восстания эстов 1343-1345 гг. против немецких и датских господ (восстание «Юрьевой ночи») и связанных с ним международных событий ${ }^{39}$. В хронике подробно говорится о походах псковичей в Ливонию. Мы остановимся на событиях майского похода 1343 г. псковичей в Дерптское епископство, синхронно описанных в «Младшей рифмованной хронике» и русских летописях.

\section{Псковский поход 1343 г. и посольство эстов}

В разделе хроники, посвященной событиям восстания «Юрьевой ночи» 1343 г., есть следующий сюжет:

«Два эста из Харрии пришли в Псков и сказали русским, что все немцы в Харрии, включая магистра и братьев Ордена, перебиты, эсты избрали себе короля; если они (русские. - Ф. П.) хотят забрать добычу (или «добыть славу». — Ф. П.), то, конечно, могут завоевать [ту] землю. Русские собрали 5000 человек, пошли походом в епископство Дерптское, грабили и жгли со всей силой, вырезали перед Одемпе людей и скот, — все что встретили на пути» ${ }^{40}$.

Ревельский хронист XVI в. Балтазар Рюссов, пользовавшийся «Младшей рифмованной хроникой» ${ }^{41}$, несколько скорректировал данный сюжет. В «Хронике» Рюссова к русским приходят не эсты из Харрии, а «другие крестьяне земли», которые хотели помочь своим «друзьям» в Харрии ${ }^{42}$. В связи с этим нам представляется справедливым

диалекте. Отрывок имеет сюжетное сходство с событиями восстания «Юрьевой ночи» 1343 г., описанными в «Ливонской истории» Реннера. Данное обстоятельство подкрепляет наш вывод.

${ }^{37}$ Die Jüngere Livländische Reimchronik... S. XIV-XX.

${ }^{38}$ На это указывает фраза «Ende des andern bokes» (конец другой книги) в конце хроники (Die Jüngere Livländische Reimchronik... S. 37).

${ }_{39}$ Vahtre S. Die Darstellung des Estenaufstandes 1343 bis 1345 in Deutschordenschroniken // Aus der Geschichte Altlivlands: Festschrift für Heinz von zur Mühlen zum 90. Geburtstag / Hrsg. von B. Jähnig und K. Militzer. Münster, 2004. S. 57.

${ }_{40}^{4} \ll \mathrm{Nu}$ weren twe Eesten uth Harrien na der Plescow gekamen unnd den Russen angebracht, wo alle Dudschen inn Harrien sampt dem meister und ordensbrodern erschlagen weren und de Eesten einen koning erwelet hedden; wolden se nu pris inleggen, so konden se dat landt wol inkrigen. Also sammelden de Russen 5000 man, togen int stift Dorpte, roveden und branden mit aller macht, erschlogen vor Odempe luide und vee, wat se anquemen» (Die Jüngere Livländische Reimchronik... S. 27-28).

${ }^{41}$ Vahtre S. Die Darstellung des Estenaufstandes... S. 57.

${ }_{42}$ "Alse nu de andern Buren im Lande, dat idt eren Fründen vor Reuel also gegan mas, hebben erer etlike den Rüssen ausgespraken, dat he sick wedderumme an de Düdeschen maken scholde, vellichte wörden em alle de Buren im Lande thofallen. De Rüsse hesst sick nicht lange gesümet, 
заключение эстонского историка Сулева Вахтре, который считал указание на Харрию позднейшим добавлением Иоганна Реннера ${ }^{43}$. Данная версия выглядит предпочтительнее: выходит, что русских могли пригласить крестьяне из владений дерптского епископа («de andern Buren im Lande»), а не люди из Харрии, которые к Дерпту отношения не имели. Тем не менее, это посольство было непосредственно связано с событиями в Харрии, на что Рюссов прямо указывает («dat idt eren Fründen vor Reuel also gegan mas»).

$\mathrm{B}$ псковских ${ }^{44}$ и новгородских летописях ${ }^{45}$ мы также встречаем упоминание о походе 5000 псковичей ${ }^{46}$ в «Немецкую землю», к «Медвежьей голове» (нем. Одемпе) 26 мая 1343 г. Однако ни в одном из летописных списков, как и в других ливонских хрониках того времени, нет истории о посольстве эстов в Псков перед русским походом. Значит, мы имеем дело с уникальным сообщением. Примечательно, что за несколько недель до русского похода, в конце апреля - начале мая 1343 г., эсты отправили посольство шведскому фогту Або (фин. Турку) со схожими предложениями:

«Затем послали они (эсты. - Ф. П.) фогту Або в Швеции за помощью, с сообщением, что все немцы в Харрии перебиты... если же они (шведы. - Ф. П.) дадут совет и помощь, то эсты хотят быть их подданными» ${ }^{47}$.

Содержание двух посольств позволяет предложить следующую реконструкцию событий. Шведский фогт Николаус прибыл в Эстонию 19 мая, русские вторгаются в земли Дерптского епископа 26 мая 1343 г. Можно выдвинуть предположение, что два посольства эстонцев были отправлены одновременно, с одними и теми же задачами ${ }^{48}$. О сути посольства к шведам Бартоломей Хёнеке мог узнать от немца-перебежчика, который был допрошен магистром после победы братьев Ордена над эстонцами под Ревелем и рассказал о сборах «больших сил» фогта Або (14 мая 1343 г. $)^{49}$. Другим вероятным источником мог быть сам фогт Або, который прибыл к городу уже после

sundern is bald int Stiffte Dörpte gefallen» (Chronica der Provinz Lyfflandt, dorch Balthasar Russowen // Scriptores Rerum Livonicarum. Bd 2 / Hrsg. von E. Pabst. Riga; Leipzig, 1848. S. 25). ${ }^{43}$ Vahtre S. Die Darstellung des Estenaufstandes... S. 63.

${ }^{44}$ Псковские летописи. Вып. 1. С. 11-12, 20; Вып. 2. С. 25-26, 97-98.

${ }^{45}$ Новгородская Первая летопись... С. 356-357, 459.

46 «Младшая ливонская рифмованная хроника» и русские летописи одинаково оценивают численность вторгнувшегося псковского войска (5000 мужей). Вряд ли это случайное сходство. Бартоломей Хёнеке, как современник событий, мог знать приблизительную численность войска, довольно большого по тем временам. Подчеркнем, что и русский летописец исходил из реальных данных.

${ }^{47}$ «Derhalben sanden se ann den vaget to Abo in Sweden umb hulpe mit vormelding, dat se alle Dudschen inn Harrien umbgebracht hedden... so he en nu guden rath und bystandt mitdelen wolde, so wolden se ohme underdanich sin» (Die Jüngere Livländische Reimchronik... S. 20).

${ }_{48} 18$ мая 1343 г., то есть за день до прихода фогта Або, в Ревель с войском прибыл фогт Выборга: «Des sondages darna quam de vaget an van Wiborch mit grotem folcke to Reval, dorfte averst nicht an lant kamen» (Die Jüngere Livländische Reimchronik... S. 26). Возможно, эсты послали послов и к фогту Выборга, однако наш хронист об этом ничего не сообщает. Во всяком случае, два фогта могли действовать согласованно.

${ }_{49}$ «Dar wort ein gefangen Dudscher, die sich uth forchten sines levendes to den Eesten gegeven hadde, vo den mester gebracht; de bekande, dat de vaget van Abo mit groter macht binnen vif dagen ankamen und den Eesten hulpe don wurde» (Die Jüngere Livländische Reimchronik... S. 25). 
поражения эстов и вел переговоры с братом Госвином фон Херике ${ }^{50}$. Согласно Рюссову, крестьяне из владений епископа Дерпта собираются помочь «своим друзьям» под Ревелем, призывая русскую рать в свои земли. Значит, перебежчик мог рассказать магистру и священнику Ордена Бартоломею Хёнеке и о посольстве эстов к русским (узнав об этом от самих восставших). Следовательно, нет оснований сомневаться в том, что автор хроники верно передал содержание схожих предложений эстонских послов в Або и Пскове. В связи с этим необходимо сравнить содержание посольств к шведам и русским. Думается, что таким образом можно было бы прояснить некоторые важные обстоятельства пребывании двух эстонцев в Пскове в мае 1343 г.

\section{ЧТО ПООБЕЩАЛИ ЭСТЫ}

Представители эстов пообещали шведам свое подданство («so wolden se ohme underdanich sin»), а русским предложили «завоевать землю» («dat landt wol inkrigen») и «захватить добычу» («wolden se nu pris inleggen») $)^{51}$. О походе русских именно с целью «завоевания земли» свидетельствует и собранное ими значительное войско в 5000 человек, подтверждаемое немецкими и русскими источниками.

Какую «землю» и «добычу» пообещали русским эсты? Вряд ли послы восставших могли сулить шведам и псковичам одни и те же области во владение: шведов явно интересовала датская Эстония (Харрия и Вирланд), не входившая в сферу интересов Пскова. Ответить на вопрос можно исходя из маршрута похода. Русские вторглись в Дерптское епископство («togen int stift Dorpte») и дошли до Одемпе («erschlogen vor Odempe luide und vee»). Согласно новгородским летописям, псковичи пошли «к Медвежьи голове» и провели в «Немецкой земле» восемь дней и ночей ${ }^{52}$. В псковских летописях говорится, что «псковичи со изборяныл» «воеваша около Медвежии голове пять днеи и пять нощеи» ${ }^{53}$. Вероятно, новгородский летописец приводит общее время похода (восемь дней), а псковский - дни, затраченные на военные действия возле Одемпе (пять дней). В любом случае, можно заключить, что одной из главных целей русских в земле Дерпт-

${ }^{50}$ Die Jüngere Livländische Reimchronik... S. 27.

${ }^{51}$ «Pris inleggen» предполагает разные варианты перевода. «Рris» может переводиться как «военная слава» (Ruhm), денежная цена («Preis, Geldwerd»), «военная добыча, трофей» (Mittelniederdeutsches Wörterbuch. Bd III / Hrsg. von K. Schiller, A. Lübben. Bremen, 1877. S. 376-377). В контексте хроники Хёнеке «pris inleggen» означает либо «добыть славу» (братья Ордена в 1342 г. «gedachte he ock pris unnd ehre inntoleggende»), либо «захватить добычу» (летты, ливы и эсты под Изборском также в 1342 г. «wolden alle pris inleggen») (Die Jüngere Livländische Reimchronik... S. 16-18). В данной статье выбран вариант «захватить добычу» по следующим соображениям. Сам хронист, чьи симпатии были на стороне Ордена, приписывает последнему мотив «чести и славы» в походе, а полуязычникам ливам, леттам и эстам - желание добычи. В связи с этим, русские должны были по приглашению язычников эстов стяжать не «славу», а «добычу».

${ }^{52}$ Новгородская Первая летопись... С. 356, 459.

${ }_{53}$ Псковские летописи. Вып. 1. С. 20. - Для жителей Изборска (их участие упомянуто только в псковских летописях) мотивом похода на землю эстов могла послужить месть: менее чем за год до этого, в августе 1342 г., эсты, летты и ливы вместе с людьми епископа Дерпта грабили скот и «резали все, что встречали» в предместьях Изборска (Die Jüngere Livländische Reimchronik... S. 17-18). Ту же фразу употребляет хронист для русского войска под Одемпе («erschlogen luide und vee, wat se anquemen») (Ibid. S. 28). 
ского епископа была «Медвежья голова». Одемпе в качестве опорного пункта сбора дани в эстонских землях интересовал русских князей еще с XIII в. ${ }^{54}$ После первой четверти XIII в. русские утратили политический контроль над Эстонией. Однако земли, входившие в состав Дерптского епископства, долгое время рассматривались псковичами как объект дани. Так, псковские «данщики» ходили собирать дань в область Толова в 1284 г. ${ }^{55}$ На притеснения со стороны русских жаловался епископ Дерпта Бернхард II $(1285)^{56}$. Таким образом, память о некогда податных территориях в Эстонии была жива у участников похода 1343 г. Отметим, что в описании похода псковичи поминают «отциов и дедов»: «сташа псковичи воополчившися противу Немец боеви... и рекоша: братие, не посрамим отец своих и дедов» ${ }^{57}$, «воеваша... не слазя с конь, где то не бывали ни omubl, ни дедu» ${ }^{58}$. Это свидетельствует о том, что для воинов Пскова и Изборска поход, помимо политического, носил характер «исторического воздаяния».

Итак, следует полагать, что два эстонца предложили псковичам завладеть землями своего господина - дерптского епископа — и восстановить владычество над некогда податными эстонскими племенами ${ }^{59}$. В таком случае предложение «захватить землю и добычу», сделанное за 211 лет до переговоров в Москве 1554 г., могло бы считаться прецедентом для «юрьевской дани». Как видим, для такого предположения есть и хронологические, и исторические основания.

\section{ДВА ПРОТИВОРЕЧИЯ}

Наша гипотеза требует решения двух противоречий. Во-первых, дьяк Иван Висковатый на московских переговорах 1554 г. назвал цифру в 210 лет, а не 211, как следовало бы по отношению к походу 1343 г. Во-вторых, почему эстонское посольство в Псков и их обещание земель дерптского епископа не упомянуты в русском летописании?

Восстание эстов 1343 г. упоминается только в новгородских летописях. В статье 6582 г. (1344) читаем: «Бысть мятеж за Наровою велик: избиша Чюдь своих бояр земских, и в Кольванскои земли и в Ругодивскои волости» ${ }^{60}$. В статье суммарно излагаются события восстания эстов 1343-1344 гг. Значит, в русской книжности восстание

${ }^{54}$ Heinrichs Livländische Chronik / Bearbeitet von L. Arbusow und A. Bauer. Hannover, 1955. S. 100-101 (поход новгородского князя Мстислава Удатного и Владимира Псковского к Одемпе в 1210 г.).

${ }_{55}^{5}$ Псковские летописи. Вып. 1. С. 14.

${ }^{56}$ «ecclesiae nostrae, quae multis undique tam paganorum quam Ruthenorum propulsatur insultibus» (Bernhard II., B. von Dorpat, und sein Capitel ersuchen den Lübischen Rath um Auslieferung der vom B. Friedrich hinterlassenen Güter, im J. 1285? // Liv-, Esth- und Curländisches Urkundenbuch. Bd I. 1093-1300 / Hrsg. von F. G. von Bunge. Reval, 1853. S. 623. № DIII). Возможна, эта жалоба как-то связана с псковскими данщиками, убитыми за год до этого.

${ }^{57}$ Псковские летописи. Вып. 1. С. 11.

${ }_{58}^{58}$ Псковские летописи. Вып. 1. С. 20; Вып. 2. С. 25, 97.

${ }_{59}^{5}$ Вряд ли владычество русских над эстами когда-либо носило постоянный характер. Имеющиеся сведения из русских летописей позволяют говорить лишь о периодических походах русских князей с целью сбора дани, основании опорных пунктов. См. подробнее: Keussler F. von. Der Ausgang der ersten russischen Herrschaft in den gegenwärtigen Ostseeprovinzen im XIII. Jahrhundert. St. Petersburg, 1897. S. 80-107; Selart A. Livland und die Rus' im 13. Jahrhundert. Köln; Weimar; Wien, 2007. S. 56-58.

${ }^{60}$ Новгородская Первая летопись... С. 357. 
«Юрьевой ночи» ассоциировалось с 1344 г. Отсюда понятно, почему Иван Висковатый назвал цифру «210»: если прецедентом дани для русской стороны было обещание отдать земли дерптского епископа, то он отождествлялся с датой восстания эстов, указанной в русском источнике.

Ни в одном из новгородских и псковских летописных списков в сюжете 6851 г. не говорится о мотивах похода такого большого войска: псковичи «поидоша в воину», «воополчившися противу Немецү», «подъемше всю свою область», «нагадавшеся с изборяныл» ${ }^{61}$. Казалось бы, такие события, как восстание эстов и их посольство в Псков, должны были отразиться в псковской летописи, предваряя таким образом статью о походе 1343 г. $^{62}$

Древнейшие из дошедших псковских летописей составлены во второй половине $\mathrm{XV}$ в. $^{63}$, известные нам списки представлены двумя сводами: 1547 г. (промосковский) и 1567 г. (пропсковский) ${ }^{64}$. Обе редакции были составлены в то время, когда история «юрьевской дани» уже неоднократно включалась в тексты русско-ливонских договоренностей и была хорошо известна в политических кругах времен Ивана IV. На наш взгляд, начиная с договора 1474 г. («дань благоверных великих князей русских изарей») ${ }^{65}$ можно проследить тенденцию к удревнению «юрьевской дани». Ко времени создания «Степенной книги» в начале 60-х гг. XVI в. утвердилась мысль о наложении «юрьевской дани» еще Ярославом Мудрым в 1030 г. ${ }^{66}$ Однако во время переговоров 1554 г. в Москве Иван Висковатый ни разу не упомянул эту историю. Дьяк сослался на текст русско-ливонского договора 1474 г, а также на известный ему прецедент начала 40-х гг. XIV в. Данный прецедент был сравнительно «недавним» и потому плохо подходил на роль «обосновывающей истории»: ведь московская дипломатия охотнее апеллировала к более ранним временам Рюрика, Владимира и Ярослава ${ }^{67}$. Приход же псковичей за «юрьевской данью» по приглашению представителей восставших выглядел как вмешательство во внутренние дела ослабленного противника и потому был неуместен в качестве идеологического прецедента для редактора второй половины XV-XVI вв. Однако в устах дьяка во время острой дипломатической дискуссии он мог послужить реальным историческим аргументом.

\section{ЗАКЛЮЧЕНИЕ}

Возможно ли по-иному рассматривать упоминание русской стороной «долга в 210 лет» во время переговоров 1554 г., чем указание на реальный исторический прецедент, о котором знал дьяк Иван Михайлович Висковатый? К сожалению, у нас нет прямых указаний источников на то событие, с которого следовало бы отсчитывать хронологию «юрьевской дани». Однако цифра в «210 лет», известная из отчета ливонских послов,

${ }_{61}^{61}$ Новгородская Первая летопись... С. 356; Псковские летописи. Вып. 1. С. 11, 20; Вып. 2. C. 25, 97.

62 Для сравнения: сюжет о походе псковского князя Александра Всеволодовича в Лотыголу в декабре 1341 г. предваряется подробным рассказом об убийстве псковских послов немцами 9 сентября 1341 г. (Псковские летописи. Вып. 2. С. 92-93).

${ }^{63}$ Псковские летописи. Вып. 1. С. ІІІ (Введение).

${ }^{64}$ Псковские летописи. Вып. 2. С. 6 (Предисловие).

${ }_{65}^{65}$ Договорная грамота Великого Новгорода и Пскова... С. 133. № 78.

${ }^{6}$ Степенная книга... С. 380-382.

${ }^{67}$ Ерусалимский К. Ю. История на посольской службе: дипломатия и память в России XVI в. // История и память: Историческая культура Европы до начала Нового времени. М., 2006. С. 703-704. 
может служить отправной точкой для поиска предлога, который русские посчитали бы достаточным для требований денежных выплат с дерптского епископа накануне Ливонской войны.

Исторический казус «юрьевской дани» следует искать в событиях восстания «Юрьевой ночи» эстов против немецких господ в 1343-1345 гг. Наиболее ценным источником для изучения восстания является «Младшая ливонская рифмованная хроника» современника событий Бартоломея Хёнеке. Этот источник не привлекался ранее в исследовании загадки «юрьевской дани». Между тем, там есть два уникальных сообщения, которые могли бы «пролить свет» на данный вопрос.

Со слов немецкого рыцаря, побывавшего в плену у эстов, Бартоломей Хёнеке передал историю о посольстве представителей восставших к шведскому фогту Або и в Псков (конец апреля - май 1343 года). Нам представляется, что содержание предложений посланников эстов шведам и русским было схожим. Сравнив сюжеты о двух посольствах, можно реконструировать картину переговоров в Пскове накануне майского похода псковичей и изборян в Дерптское епископство в 1343 г.

Посланники эстов пообещали шведам земли в северной Эстонии, а русским - территорию Дерптского епископства. Обещанные псковичам «земля и добыча» не были просто риторическим оборотом. Русские претендовали на земли дерптского епископа с конца первой четверти XIII в. и пытались собирать с нее дань в конце столетия (1284). Вот почему псковский летописец поминает «отцов и дедов» в рассказе о походе 5000 псковичей и изборян в «Немецкую землю».

На наш взгляд, посольство старейшин эстов в Псков в 1343 г., обещание ими «земли» и «добычи», последующий поход псковского войска в Дерптское епископство в мае 1343 г. могут являться тем самым историческим поводом, который русская сторона впоследствии интерпретировала как даннические обязательства, признание исторических прав Руси над Эстонией. В смысле «политики памяти» было не столь важно, кто именно - сами эсты или дерптский епископ — «пообещали» подданство. Важно было найти прецедент из относительно недавнего прошлого (XIV век), с помощью которого можно было выстроить линию преемственности «юрьевской дани», «заставить» ливонских послов подписать перемирие 1554 г. и поддержать память о Русской Ливонии.

\section{Информация о статье}

Автор: Подберёзкин, Филипп Дмитриевич - младший научный сотрудник, Отдел редких книг и рукописей, Центральная научная библиотека им. Я. Коласа Национальной Академии наук Республики Беларусь, Минск, Беларусь, OrcID 0000-0001-7471-8793, e-mail: hetmanpolny@yandex.ru

Заголовок: Когда появилась юрьевская дань?

Резюме: В статье рассматривается вопрос о времени появления «юрьевской дани» — исторического налога дерптского (юрьевского) епископа в пользу великих князей московских. Основываясь на цифре в 210 лет «неуплаченной дани», которую привел дьяк Иван Висковатый во время русско-ливонских переговоров 1554 г., делается попытка определить, какое событие легло в основу хронологических построений русской стороны. На взгляд автора, прецедент следует искать в событиях «Юрьевой ночи» - восстания эстов против немецких господ в 1343-1345 гг. На основе важнейшего источника для данного периода, «Младшей ливонской рифмованной хроники» Бартоломея Хёнеке, делается сравнительный анализ сюжетов о посольстве эстов к шведскому фогту Або и в Псков в конце апреля-мае 1343 г. Восставшие предложили псковичам земли дерптского епископа и свое подданство, после чего большое войско Пскова и Изборска вторглось во владения епископа. Важно отметить, что псковичи издавна рассматривали эти земли как «свои», что отразилось в риторике псковских летописей. Позднее содержание посольства эстов могло расцениваться как обязательство подчиненной стороны уплачивать 
дань с земель Дерпта («юрьевская дань»). Вследствие того, что восстание эстов в русской книжности отождествлялось с 1344 годом, можно объяснить, почему от 1554 к 1344 г. отсчитывалось 210, а не 211 лет. В связи со сказанным автор полагает, что посольство эстов в Псков в мае 1343 г. можно считать историческим прецедентом «юрьевской дани».

Ключевые слова: юрьевская дань, «Младшая ливонская рифмованная хроника», эсты, Псков, Дерпт, Ливонский вопрос

\section{Литература, использованная в статье:}

Баранов, Александр Викторович. Русско-ливонские договоры 1474 года: предпосылки, переговоры, последствия // Средневековая Русь. 2016. Вып. 12. С. 201-282.

Ерусалимский, Константин Юрьевич. История на посольской службе: дипломатия и память в России XVI в. // История и память: Историческая культура Европы до начала Нового времени / Отв. ред. Л. П. Репина. Москва: Кругъ, 2006. С. 664-732.

Казакова, Наталья Александровна. Русь и Ливония 60-х - начала 90-х годов XV века // Международные связи России до XVII в. Москва: Изд-во АН СССР, 1961. С. 306-333.

Мартынюк, Алексей Викторович. Между Псковом, Витебском и Нейгаузеном: забытая война на ливонском пограничье в середине XIV века. Часть 1 // Ученые записки УО «Витебский государственный университет им. П. М. Машерова». Витебск, 2016. Т. 21. С. 30-36.

Мартынюк, Алексей Викторович. Между Псковом, Витебском и Нейгаузеном: забытая война на ливонском пограничье в середине XIV века. Часть 2 // Ученые записки УО «Витебский государственный университет им. П. М. Машерова». Витебск, 2016. Т. 22. С. 33-38.

Филюшкин, Александр Ильич. Изобретая первую войну России и Европы. Балтийские войны второй половины XVI в. глазами современников и потомков. Санкт-Петербург: Дмитрий Буланин, 2013. 880 с. Филюшкин, Александр Ильич; Попов, Вадим Евгеньевич. Русско-ливонские договоры 1554 г. // Studia Slavica et Balcanica Petropolitana. 2010. № 1 (7). C. 109-130.

Шаскольский, Игорь Павлович. Русско-ливонские переговоры 1554 года и вопрос о ливонской дани // Международные связи России до XVII в. Москва: Изд-во АН СССР, 1961. С. 376-399.

Mentzel-Reuters, Arno. Bartholomaeus Hoeneke. Ein Historiograph zwischen Überlieferung und Fiktion // Geschichtsschreibung im mittelalterlichen Livland / Hrsg. von Matthias Thumser. Berlin: Lit Verlag, 2011. S. 11-58.

Selart, Anti. Der «Dorpater Zins» und die Dorpat-Pleskauer Beziehungen im Mittelalter // Aus der Geschichte Altlivlands: Festschrift für Heinz von zur Mühlen zum 90. Geburtstag / Hrsg. von Bernhart Jähnig und Klaus Militzer. Münster: Lit Verlag, 2004. S. 11-37.

Selart, Anti. Livland und die Rus' im 13. Jahrhundert. Köln; Weimar; Wien: Böhlau Verlag, 2007. 373 s. Selart, Anti. Livland - ein russisches Erbland? // Russland an der Ostsee. Imperiale Strategien der Macht und kulturelle Wahrnehmungsmuster / Hrsg. von Karsten Brüggemann und Bradley D. Woodworth. Wien; Köln; Weimar: Böhlau Verlag, 2012. S. 29-66.

Vahtre, Sulev. Die Darstellung des Estenaufstandes 1343 bis 1345 in Deutschordenschroniken // Aus der Geschichte Altlivlands: Festschrift für Heinz von zur Mühlen zum 90. Geburtstag / Hrsg. von Bernhart Jähnig und Klaus Militzer. Münster: Lit Verlag, 2004. S. 55-69.

Information about the article

Author: Porberyozkin, Philip Dmitrievich - Junior Researcher, Department of Rare Books and Manuscripts, Central Scientific Library of the National Academy of Sciences of Belarus, Minsk, Belarus, OrcID 0000-0001-7471-8793, e-mail: hetmanpolny@yandex.ru

Title: When did the tribute of Dorpat appear?

Summary: The article examines the origin of the «tribute of Dorpat», historical tax of Bishops of Dorpat (Yuryev) to Grand Princes of Moscow. Study is based on chronological information, provided by Russian Diplomat Ivan Viskovatiy during the Russian-Livonian negotiations in 1554. According to Viskovatiy, the tribute was not paid by Livonians for 210 years. The author tries to find out, what historical event commenced the chronology of the «unpaid tribute», as called by Russians. From the author's point of view, the historical precedent can be found in the events of Saint George's Night Uprising of Estonians against German and Danish Lords in 1343-1345. The author compares two stories about the negotiations of Estonians with the Swedish Vogt of Abo and with Pskov in late April and early May of 1343, using the most important source for this period, «The Younger Livonian Rhymed Chronicle» by Bartholomeus Hoeneke. After the rebels offered Pskov the lands of Bishop of Dorpat as well as their allegiance, the big army of Pskov and Izborsk attacked 
the Bishopric. It important to note, that, according to the Pskov chronicles, Pskovians considered these lands their own. In 1554 the offers of Estonian diplomats could have been viewed as the tribute proposal from the territories of Dorpat («Dorpat tribute»). The Saint George's Night Uprising in the Russian literary tradition is associated with 1344. Therefore, the Russian diplomats in 1554 counted 210 years from that event, instead of 211. Thus the author concludes, that the proposals of Estonians in Pskov in May 1343 can be viewed as a historical precedent, that commenced the chronology of the «tribute of Dorpat».

Keywords: «tribute of Dorpat», «Younger Livonian Rhymed Chronicle», Estonians, Pskov, Dorpat, Livonian crisis

\section{References:}

Baranov, Aleksandr Viktorovich. Russko-livonskie dogovory 1474 goda: predposylki, peregovory, posledstviya [The Russian-Livonian treaties of 1474: conditions, negotiations, consequences], in Srednevekovaya Rus'. 2016. Vol. 12. Pp. 201-282. (in Russian).

Erusalimskiy, Konstantin Yuryevich. Istoriya na posol'skoy sluzhbe: diplomatiya i pamyat' v Rossii XVI v. [History at diplomatic service: diplomacy and memory in the $16^{\text {th }}$ century in Russia], in Repina, Lorina Petrovna (Ed.). Istoriya i pamyat': Istoricheskaya kul'tura Evropi do nachala Novogo vremeni. Moscow: Krug Publ., 2006. C. 664-732. (in Russian).

Filyushkin, Aleksandr Ilyich. Izobretaya pervuyu voynu Rossii i Evropy. Baltiyskie voyny vtoroy poloviny XVI v. glazami sovremennikov i potomkov [Making the First War between Russia and Europe. Baltic Wars of the second half of the $16^{\text {th }}$ century by the eyes of contemporaries and descendants]. St. Petersburg: Dmitriy Bulanin Publ., 2013. 880 p. (in Russian).

Filyushkin, Aleksandr Ilyich; Popov, Vadim Evgenyevich. Russko-livonskie dogovory 1554 g. [The RussianLivonian treaties of 1554], in Studia Slavica et Balcanica Petropolitana. 2010. No. 1 (7). Pp. 109-130. (in Russian). Forsten, Georgiy Vasilyevich. Baltiyskiy vopros v XVI i XVII stoletiyakh (1544-1648). T. 1. Bor'ba iz-za Livonii [Baltic Question in the $16^{\text {th }}-17^{\text {th }}$ centuries. Vol. I: Struggle for Livonia]. St. Petersburg: V. S. Balashev i $\mathrm{K}^{\circ}$ Print. House, 1893.717 p. (in Russian).

Kazakova, Natalya Aleksandrovna. Rus' i Livoniya 60-kh - nachala 90-kh godov XV veka [Russia and Livonia in the $60 \mathrm{~s}$ - beginning of the $90 \mathrm{~s}$ years of the $15^{\text {th }}$ century], in Mezhdunarodnye svyazi Rossii do XVII v. Moscow: Academy of Sciences of the USSR Press, 1961. Pp. 306-333. (in Russian).

Martynyuk, Aleksey Viktorovich. Mezhdu Pskovom, Vitebskom i Neygauzenom: zabytaya voyna na livonskom pograniche v seredine XIV veka. Chast' 1 [Between Pskov, Vitebsk and Neuhausen: the forgotten war on the livonian frontier in the middle of the $14^{\text {th }}$ century. Part 1], in Uchenye zapiski UO «Vitebskiy gosudarstvennyy universitet im. P. M. Masherova». Vitebsk, 2016. Vol. 21. Pp. 30-36. (in Russian).

Martynyuk, Aleksey Viktorovich. Mezhdu Pskovom, Vitebskom i Neygauzenom: zabytaya voyna na livonskom pograniche v seredine XIV veka. Chast' 2 [Between Pskov, Vitebsk and Neuhausen: the forgotten war on the livonian frontier in the middle of the $14^{\text {th }}$ century. Part 2], in Uchenye zapiski UO «Vitebskiy gosudarstvennyy universitet im. P. M. Masherova». Vitebsk, 2016. Vol. 22. Pp. 33-38. (in Russian).

Mentzel-Reuters, Arno. Bartholomaeus Hoeneke. Ein Historiograph zwischen Überlieferung und Fiktion [Bartholomaeus Hoeneke. The Historiographer between tradition and fiction], in Thumser, Matthias (ed.). Geschichtsschreibung im mittelalterlichen Livland. Berlin: Lit Verlag Publ., 2011. Pp. 11-58. (in German). Selart, Anti. Der «Dorpater Zins» und die Dorpat-Pleskauer Beziehungen im Mittelalter [The «tribute of Dorpat» and the Dorpat-Pskov relations in the Middle Ages], in Jähnig, Bernhart; Militzer, Klaus (eds). Aus der Geschichte Altlivlands: Festschrift für Heinz von zur Mühlen zum 90. Geburtstag. Münster: Lit Verlag Publ., 2004. Pp. 11-37. (in German).

Selart, Anti. Livland und die Rus' im 13. Jahrhundert [Livonia and the Rus' in 13 ${ }^{\text {th }}$ century]. Köln; Weimar; Wien: Böhlau Verlag Publ., 2007. 373 p. (in German).

Selart, Anti. Livland - ein russisches Erbland? [Livonia - the Russian patrimony?], in Brüggemann, Karsten; Woodworth, Bradley D. (eds). Russland an der Ostsee. Imperiale Strategien der Macht und kulturelle Wahrnehmungsmuster. Wien; Köln; Weimar: Böhlau Verlag Publ., 2012. Pp. 29-66. (in German).

Shaskol'skiy, Igor' Pavlovich. Russko-livonskie peregovory 1554 goda i vopros o livonskoy dani [The Russian-Livonian negotiations of 1554 and the issue of the Livonian tribute], in Mezhdunarodnye svyazi Rossii do XVII v. Moscow: Academy of Sciences of the USSR Press, 1961. Pp. 376-399. (in Russian).

Vahtre, Sulev. Die Darstellung des Estenaufstandes 1343 bis 1345 in Deutschordenschroniken [The representation of the Estonian Uprising from 1343 to 1345 in the chronicles of Teutonic Order], in Jähnig, Bernhart; Militzer, Klaus (eds). Aus der Geschichte Altlivlands: Festschrift für Heinz von zur Mühlen zum 90. Geburtstag. Münster: Lit Verlag Publ., 2004. Pp. 55-69. (in German). 